\title{
Educational Process of Exceptional Children in Special Education Waraqil Jannah School
}

\author{
Retno Maya Sari', Fatmariza', Muhamad Hendro² \\ 1 Universitas Negeri Padang, Indonesia \\ 2Institut Agama Islam Negeri Salatiga, Indonesia
}

Corresponding Author: Retno Maya Sari, @retnomaya2@gmail.com

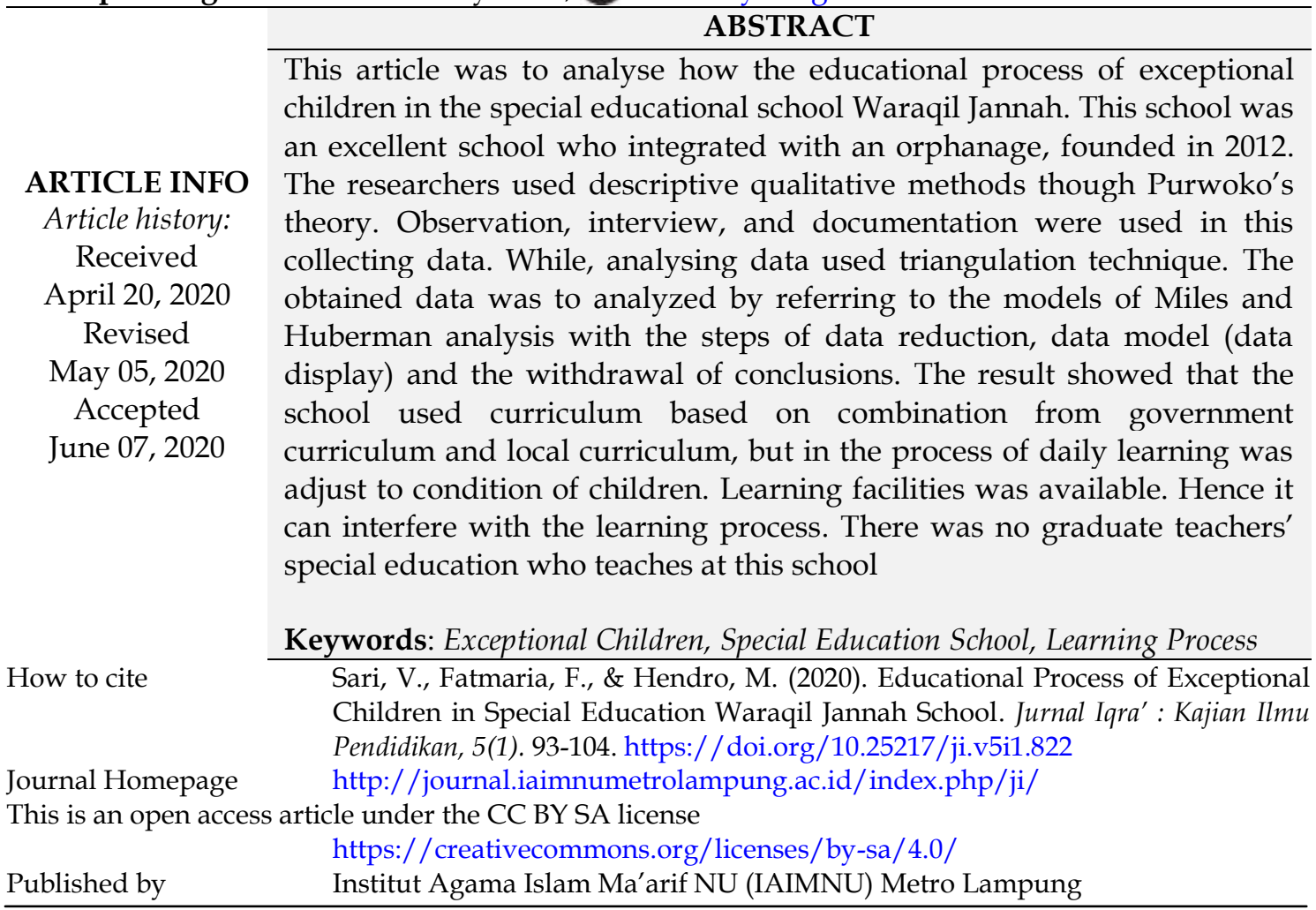

\section{INTRODUCTION}

Exceptional children are those who have problems or obstacles in their growth both physically, psychics, mentally, socially, and emosial (Desiningrum, 2017). Exceptional Children or Anak Berkebutuhan Khusus (ABK) are children who have barriers in their development either physically, mentally, socially, or emotionally so that requires a special service. However, each child has the same rights including the right of education, regardless of the normal or absence of the child. But in fact exceptional children often get unpleasant treatment. Elisa \& Wrastari (2013) reported that there is a child who has a physical barrier which is decline to attend a vocational high school. The same opinion also conveyed by (Triyanto \& Permatasari, 2016) that in 2016 there was a case of violence committed by the school against children with special needs, causing physical injury. It the same as $\mathrm{Mu}^{\prime}$ ammar (2017) who convey that here are still often occurs hate speech and bullying of exceptional children performed by peers. 
To minimize the violence of children with special needs, the government made regulations that could protect the children such as LAW No. 4 of 1997 on the disabled, LAW No 19 Year 2011 on the ratification of the Convention on Rights of Disability, until the latest LAW No. 8 year 2016 about the disability. In addition, civil and political rights are governed by the rights of children who are part of a human right that must be guaranteed, protected and fulfilled by parents, families, communities, governments and countries. In the right of the child itself is explained that the child has the right to obtain education. From the LAW it can be seen that the government has paid more attention to children with special needs. Education for exceptional children is not much different from education for normal children, only adapted to talents, interests, abilities, \& students ' abnormalities, such as Sekolah Luar Biasa (SLB) or Special Education Curriculum who used national Curriculum and local content curriculum. The study Pramartha (2015) \& Sunardi (2010) discussed that the special education is an educational institution to hold Pendidikan Luar Biasa (PLB), especially children with disabilities. In West Sumatera, precisely in Nagari Ogan, there is an special education school who integrated with an orphanage. The name is Waraqil Jannah School. Total of the exceptional children were 49, and 29 children who school and live in the orphanage.

Recent years, many researchers who cared and studied about learning process of exceptional children. The first, Faridah, Arismunandar, \& Bernard, (2018) discussed that the schools have dormitories are considered as one of the alternatives to train the children's character to be more independent, selfcontained, and training child sensitivity through the special character on themselves. Hopefully Through a boarding life can be created a comprehensive and holistic education that focuses not solely on the learning system in schools, but can train children to live independently accompanied by good social skills. In addition, boarding schools are considered to help students focus more on learning and are not affected by outside environments that could have a bad impact on them. Similarly, the same research Hendriyenti (2014) explained that the boarding schools are able to improve student discipline and improve students ' religious knowledge through special programs designed by the school in accordance with school needs and children's education. One of the advantages of this boarding school is that the school is able to control children at any time, and can instill the value of discipline and religious value in children outside study. Syafe'i (2017) in his research explained that boarding school as one of the national education sub system that indigenous Indonesia, even viewed by many people, that pesantren has the special advantages and characteristics in applying character education to the students (santri). It happens because pesantren is considered easier to build educational character. This research was different from the current research that analyse how the educational process of exceptional children in the special educational school Waraqil Jannah. This school specialized integrated with children's education orphanage with special needs through an integrated school 


\section{METHODS}

This research was conducted at the Waraqil Jannah who located at Jorong Hilir Balai, Tanah Datar sub-district, West Sumatera. It was descriptive qualitative method (Merriam \& Grenier, 2019; Moser \& Korstjens, 2018). Observation, Interview and documentation were used in this collecting data. The informant of the research was headmaster of Special Education Waraqil Jannah, (Yusni, M.Pd), teachers (Purwari, S.Pd, Minanda, S.Pd, Ilham, S.Pd and Lastri, S.Pd), parents and 3 children who can be invited to communicate directly. Technique collection data used observation, in-depth interviews and documentation. Observation was done with the aim of finding the facts in field by looking at the extent of the education process of exceptional children. This observation technique is done by digging information related to research objects such as observing children's activities as well as their interactions with school environment and orphanage. The interview was conducted to know the process of education of exceptional children in school and orphanage. In using depth interview the researcher interviewed headmaster, teachers, children, and the children's parents. In documentation the got Waraqil Jannah's school profile, student profiles, teacher profile, and other documents that can help the researchers. This documentation was equipped with recorder and camera devices that can record conversations or interviews with the informant, and can take pictures or videos for the needs of researchers. Analysing data used triangulation, for instance by referring to the models of Miles and Huberman analysis (Gunawan, 2013), with the steps of data reduction, data model (data display) and the withdrawal of conclusions.

\section{RESULT AND DISCUSSION}

The researchers analysed how the process of education to exceptional children in the special educational school that is integrated with the orphanage. Researchers analyzed using Purwoko's theory (Purwoko, 2017), who focus on curriculum, education facilities, students, and teachers.

Curriculum was an educational plan that has a very strategic position so that in its stacking should refer to a strong and sturdy foundation (Azis, 2018) . The learning approach used in this school is a thematic approach and a nonthematic approach. The thematic approach consists of the subjects of Pancasila and Civic Education (PPKn), Bahasa Indonesia, Mathematics, Science, IPS, and arts and culture. Special for grades 1, 2, 3 SDLB are not study subjects science and IPS. Non-thematic approaches consist of subjects of religious education and ethics; Physical Education of sports and health for class IV, V, VI; and special Needs Program. At the Special Education Waraqil Jannah School curriculum used refers to the KTSP and 2013 curriculum, but on the implementation in adjusting to the conditions and needs, as result interview from Dila Ratih Purwari, S. Pd that: "Administratively, the learning process starts at 08.00 am to $12.00 \mathrm{pm}$ for low grade, the elementary school level and the hours of $08.00 \mathrm{am}$ to $13.20 \mathrm{pm}$ for high class that is Junior High School and Senior High School level, but in fact the learning process is adjusted to the situation and conditions" 
(Purwari, 2019). It the same of interview results by Putri Minanda who said that "The learning process for exceptional children should be adjusted to the situation and conditions, not to be confused with other public schools" (Minanda, 2019). The focus of the exceptional children is only 1 to 2 hours so that the material taught should be adjusted. If normal or regular school for 1 material can be completed in 1 meeting but different from these children who completed the material in 3 even up to 4 times the meeting. Headmaster also said that Do not forcing the learning to students if the learning interest is not there, but do the approach that makes students happy, who can provoke his learning interest (Yusni, 2019).

From the result interviews can be concluded that the teaching and learning process carried out at the school is adjusted to the situation and conditions of the students. Nevertheless, the process of developing talent and interest continues to be done either in the school or outside classroom, because some children stay in the orphanage of Waraqil Jannah, so that children can carry out the learning process at any time, children can develop and practice their potential, talents, and interests. According to the observations of this special education school researcher more focused on the development of interest because a lot of art competitions won by this school include: the $3^{\text {rd }}$ winner representing West Sumatra arranging flowers in Bandung on October, 03,2019; the $1^{\text {st }}$ winner of flower arrangement of West Sumatra province on September, 24,2019; the 2nd winner of paint SMPLB level ofWest Sumatera province, several champions at the Festival and Art competition National Students (FLS2N) SLB held in the city of Padang on August, 07-10,2019, namely the $1^{\text {st }}$ Winner of Painting, the $1^{\text {st }}$ winner of singing, the $3^{\text {rd }}$ winner on singing on SD level, the $3^{\text {rd }}$ winner of Dance creations; the $3^{\text {rd }}$ winner of O2SN Padang Panjang city level; the $3^{\text {rd }}$ winner of Run level West Sumatera province; the $2^{\text {nd }}$ winner of MTQ level West Sumatera province. Marani (2017) explained that in the evaluation of learning for exceptional children teachers do not need to be overly concerned with the cognitive assessment because the average child needs to have low intelligence, but the teacher can focus on the affective and psychomotor assessment. The same thing is also conveyed by (Dermawan, 2013) That the learning model of students with special needs is trained by the school to allow students to interact with the social environment that is specially arranged through the digging of students ' self-skills based on the curriculum.

From the explanation above, it can be seen that the learning done in this school use the government curriculum and added to the local curriculum, but in the process adapted to the situation and condition of students. The school focuses more on the development of the potential, talents, and interests of students who can do exercises either in the class or outside the class.

Education facility.

Learning facilities are everything that facilitates the learning process. As delivered by Wijayanto (2017), the existence of facilities in an educational institution can support the academic and non-akamedik activities of students and support the realization of a conducive teaching and learning process. The 
same opinion is also conveyed by Nasrudin \& Maryadi (2018) that education will never go well without adequate facilities. Kurniawan (2017) said that the availability of qualified infrastructure will encourage the implementation of active learning creative Effective. For exceptional children the facilities available are important factors for the learning process. Educational facilities for exceptional children are governed in the regulation of the Indonesian Minister of National Education number 33 year 2008 about the standard of facilities and infrastructures for the special education elementary School (SDLB), the special education Junior High School (SMPLB), and the Special Education High School (SMALB).

The Facilities at the school special education are similar as the facilities in public schools, the difference lies from the number of rooms and functions of the room equipped with tools that suit the needs of children, such as Braille for children with blind or wind up to train the sound of deaf children, as well as bells, bell that can be used to train residual hearing for deaf children (Ilham, 2019). From the research shows that there are lacking facilities on the Waraqil Jannahs' special education, there are only five classroom for all students, the condition of the student class room is not conductive. Because the division of the classroom with a chalkboard or table makes the atmosphere in the classroom of SLB Waraqil Jannah is uncomfortable both to see and to use as a space for learning. In one class room is usually filled by two or three learning groups, this un conducive learning condition as also felt by the teacher. They have difficulty in delivering the subject matter because of the disruption of the learning concentration of both students and teachers who teach in one classroom. For operational means such as tables, chairs, whiteboards already exist and in quite good condition (Lastri, 2019). Then the teacher's room and library are in one room. And there is no special room for exceptional children for training such as therapy rooms, self-service halls, or skill rooms. Study from Mustafa, AR, \& Niswanto (2018) reported that there are still many special educations in ACEH whose facilities are incomplete and even tend to be virtually unavailable. It the same as statement from Novita (2017) who explained that there are still many learning facilities in Indonesian schools that have not been adequate so as not to contribute to the process of education optimally and meaningful. From the explanation above, it can be seen that the e special education in Waraqil Jannah still in lack learning facilities that can interfere with the smooth learning process.

Learners are the target of education. As stated by (Kirom, 2017) that learners are immature humans that require teaching, training, and guidance from adults. Similarly, it is listed in the LAW No. 20 of 2003 about Sisdiknas stating that students are members of the community who are trying to develop their own potential through the learning process found in specific pathways, levels, and types of education. While, Harahap (2016) explained that students are not only children who are not mature but all life-long human beings are always growing. The explanation can be concluded that learners are human beings who need learning process and guidance in order to always develop. 
Similarly, children born with disorder condition are also students who need to be guided to develop their potential, talents, and interests. In the minimum standard of education PLB explained that students in PLB are learners who have physical \& or mental disorders along with social \& behaviours, which includes impaired visual impairment, deaf, mild disabled, disabled is under the right, Tunalaras, \& who are aged $4-18$ \& highest aged 22 years. In a class or group learning the number of learners for TKLB is ideally 8 people, for SDLB, SMPLB, and SMALB are 5 people. From research that researchers have done in knowing that there are 49 children with special needs, 20 of them are children who attend school and stay in the orphanage, while 29 others only go to school. The children in Waraqil Jannah consist of various types of disabilities. There are 11 children who are at high school level, 6 people in SMP level, and 32 children at SD level which are divided according to their type of usefulness. From this explanation, all children who are in Waraqil Jannah are children with the necessary needs to develop their potential, talents, and interests.

In the educational system, the teacher's role is crucial, as conveyed by D. W. Hapsari \& Prasetio (2017) teachers have an important role to change the behavior and thinking of learners toward achieving educational objectives. Therefore, the work of teachers can not be done by any person. As stated in the law of RI number 14 of 2005 about teachers and Lecturers chapter I, article 1, paragraph 1 explains that teachers are professional educators with the primary task of educating, teaching, guiding, directing, training, assessing, and evaluating learners, at early childhood educators of formal education pathways, primary education, first education and secondary education. In order to make the process of learning to be smooth needed teachers who have competence in their field as presented by Nuraidah (2013) teachers as professionals mean that the work of teachers can only be done by someone who has academic qualifications, competence, and certificate of educators according to the requirements for each specific type and level of education. As well as teachers who teach children with disabilities. As conveyed by (Hapsari \& Mardiana, 2016) "In his research that teachers who teach children have a more several task than teachers who teach in ordinary school, because teachers who teach exceptional children must be faced with children with different characteristics". The same reported also conveyed by Istiqomah (2015) that teachers who teach the exceptional children have a special responsibility, therefore teachers should have the desire to be teachers of exceptional children and have qualifications to teach the exceptional children. Not much different from Danim (2012) also explained that to be special education education teacher cannot be done by just anyone because PLB teachers are required to have special expertise and skills, have strong loyalty and commitment in carrying out work and are based on clear scientific disciplines. It is also stated in the PLB minimum education standard which states that: Class teachers at TKLB \& SDLB are at least graduates of SGPLB; Special program teachers at least graduated from SGPLB $\&$ have attended training in accordance with the specific areas for which they 
are responsible; Subject teachers / skills education at least graduated from SGPLB \& have attended training in the field of study / skills in accordance with their responsibilities; The clinical guidance / career guidance teacher is at least a graduate of BP or PLB or educational psychology programs.

From research conducted by researchers at the special educational school Waraqil Jannah, there are 12 teachers in this school with an age range of 25-31 years, outside the age of the principal or founder of the foundation. 5 teachers came from art majors, 3 majors in Islamic education, 1 person in mathematics, 1 person in PG PAUD, 1 in Islamic sociology (Yusni, 2019). Although there are no qualified teachers in the field of special education education, the children of special education school are able to win various races especially the art race. In some studies it is explained that teachers who have no competency in teaching exceptional children can still teach the children. Sukardi (2014) explained that non-PLB teachers are able to understand the physical deficiencies of students, able to understand the theory of learning, and to facilitate the potential of students through curricular and extracurricular activities such efforts can be done with trainings and learning spirit to add insight into both the book, the Internet, and the environment. Caturwangi, Budiyanto, \& Wahyudi (2017) reported thatt non-Plb teachers can teach exceptional children through the efforts of one of the competence training of SLB teachers organized by the Education Office of Youth and Sports provision of Bali, in the training has been sought quality improvement Program of teacher SLB in Bali province; Training materials in accordance with the principles of exceptional children learning; And the learning planning process for teachers who still need a mentoring process. Although non-Plb teachers can teach children with special needs, it does not mean that there are no obstacles, even non-Plb teachers have greater obstacles or obstacles than those who have competence, such as those conveyed (Hendriani, 2014), difficult to understand learners because it consists of various characteristics; Communicating with exceptional children students is not easy although it can use body language; and lack of learning media can impede the learning process. Through ongoing training activities and learning processes can make teachers understand children with disabilities. The explanation can be concluded that in the special educationa school Waraqil Jannah does not have a teacher who is a graduate from special education, although the teachers can still teach exceptional children through training that can develop the skills of the teacher.

\section{CONCLUSIONS}

Exceptional children are those who have problems or obstacles in their growth both physically, psychics, mentally, socially, and emounky. However, each child has the same rights including the right of education, regardless of the normal or absence of the child. One of the schools dedicated to exceptional children is a special education. The results of the research is explained that there were important things to be considered in the educational process : 1) The curriculum used is the government curriculum coupled with the local 
curriculum but in the process of daily learning is adjusted to the condition of children; 2) Learning facilities available in this school are still very lacking so that it can interfere with the learning process; 3) Students in this school amounted to 49 people consisting of various confidentiality and various levels of education; 4) Teachers who teach at this school ,no one is a graduate from special education

\section{ACKNOWLEDGMENTS}

The author thanked to Mrs. Susi Fitria Dewi, S. Sos., M. Si., Ph.D as chairman of the Magister education Program of Pancasila and the nationality that has motivated the author to immediately complete this research and the author thanked to Mrs. Yusni as the principal and founder and chairman of the Foundation Waraqil Jannah who has given the author permission to conduct research in the Special Education of Waraqil Jannah land West Sumatra.

\section{AUTHOR CONTRIBUTION STATEMENTS}

Retno Maya Sari (RMS) conducts preliminary studies to obtain preliminary data, then formulates the topic of research and discusses with Fatmariza. The research started with early observation and then formulated the problem and did research. The results of the study in tests by two lecturers then revise.

\section{REFERENCES}

Azis, R. (2018). Implementasi pengembangan kurikulum. Jurnal Implementasi Pengembangan Kurikulum, VII(1), 4450.https:/ / doi.org/10.24252/ip.v7i1.4932.

Caturwangi, D. K., Budiyanto, \& Wahyudi, A. (2017). Competence of Non-PLB Teachers' Teams ( Preparation and Performance Impact Assessment ) Kompetensi Guru SLB Non-PLB ( Kajian Penyiapan dan Implikasi Kinerja ). Jurnal Peneliti Dan Pengembangan Pendidikan Luar Biasa, 4(1), 79-84. http:/ / dx.doi.org/10.17977/um029v4i12017p079 .

Danim, S. (2012). Pengembangan Profesi Guru. Prenada Media.Google Scholar.

Dermawan, O. (2013). Strategi pembelajaran bagi anak berkebutuhan khusus di slb. Psympathic: Jurnal Ilmiah Psikologi,6(2), 886-897. https:// doi.org/10.15575/psy.v6i2.2206.

Desiningrum, D. R. (2017). Psikologi anak berkebutuhan khusus. Google Scholar.

Elisa, S., \& Wrastari, A. T. (2013). Sikap guru terhadap pendidikan inklusi ditinjau dari faktor pembentuk sikap. Jurnal Psikologi Perkembangan dan Pendidikan, 2(01), 1-10.. Google Scholar.

Erawati, I. L. (2016). Pendidikan Karakter Bangsa pada Anak Berkebutuhan Khusus dalam Pendidikan Inklusif (Doctoral dissertation, Universitas Lampung).. Google Scholar.

Faridah, F., Arismunandar, A., \& Bernard, B. (2019). Sekolah Berasrama Di Sulawesi Selatan. Lentera Pendidikan: Jurnal Ilmu Tarbiyah dan 
Keguruan, 21(2), 142-153.. https:/ / doi.org/10.24252/lp.2018v21n2i1.

Gunawan, I. (2013). Metode penelitian kualitatif. Jakarta: Bumi Aksara, 143. Google Scholar

Hapsari, D., \& Prasetio, A. (2017). Pengaruh Kompetensi Guru Terhadap Prestasi Belajar Siswa Smk Negeri 2 Bawang.eProceedings of Management, 4(1).. Google Scholar.

HAPSARI, I. I., \& MARDIANA, M. (2016). Empati dan motivasi kerja guru sekolah luar biasa. JPPP-Jurnal Penelitian dan Pengukuran Psikologi, 5(1), 4856.. https:// doi.org/10.21009/JPPP.051.07.

Harahap, M. (2016). Esensi Peserta Didik dalam Perspektif Pendidikan Islam. Jurnal Pendidikan Agama Islam Al-Tharigah, 1(2), 140-155.. https:// doi.org/10.25299/althariqah.2016.vol1(2).625 .

Hendriyenti, H. (2014). Pelaksanaan Program Boarding School Dalam Pembinaan Moral Siswa Di Sma Taruna Indonesia Palembang. Ta'dib: Journal of Islamic Education (Jurnal Pendidikan Islam), 19(02), 203-226.Google Scholar.

Istiqomah, D. P. (2015). Dinamika empati guru Anak Berkebutuhan Khusus (ABK) di SDLB Putra Jaya Malang (Doctoral dissertation, Universitas Islam Negeri Maulana Malik Ibrahim).. Google Scholar.

Ilham. (2019, 10 March). The Result Interview, Teacher Special Education Waraqil Jannah, at Tanah Datar sub-district, West Sumatera

Kirom, A. (2017). Peran guru dan peserta didik dalam proses pembelajaran berbasis multikultural. Al Murabbi, 3(1), 69-80. Google Scholar.

Lastri. (2019, 20 February). The Result Interview, Teacher Special Education Waraqil Jannah, at Tanah Datar sub-district, West Sumatera

Lutfaidah, A. (2016). Pelaksanaan Pembelajaran Ppkn Bagi Anak Berkebutuhan Khusus: Studi Tentang Pembelajaran Ppkn Pada Kelas Viii Tunagrahita Smplb-C Slb Negeri Gedangan-Sidoarjo. Kajian Moral dan Kewarganegaraan, 2(4).. Google Scholar.

Kurniawan, N. (2017). Pengaruh Standart Sarana Dan Prasarana Terhadap Efektifitas Pembelajaran Di TK Al-Firdaus. Jurnal Warna: Jurnal Pendidikan Dan Anakelajaran Usia Dini, 2. http:/ / dx.doi.org/10.24903/jw.v2i2.191.

Marani, A. (2017). Kurikulum Bagi Anak Berkebutuhan Khusus (ABK). Jurnal Studia Insania, 5(2), 105-119.. https:/ / dx.doi.org/10.18592/jsi.v5i2.1358.

Minanda. (2019, 2 March). The Result Interview, Teacher Special Education Waraqil Jannah, at Tanah Datar sub-district, West Sumatera

Merriam, S. B., \& Grenier, R. S. (2019). Qualitative Research in Practice: Examples for Discussion and Analysis. John Wiley \& Sons. Google Scholar.

Moser, A., \& Korstjens, I. (2018). Series: Practical guidance to qualitative research. Part 3: Sampling, data collection and analysis. European Journal of General Practice, 24(1), 9-18. https:// doi.org/10.1080/13814788.2017.1375091

Mu'ammar, muhammad A. (2017). Hate Speech Dan Bullying Pada Anak Berkebutuhan Khusus (Studi Kasus di Sekolah Inklusi Model di 
Kabupaten Gresik). Pendidikan Islam, 8(1), 19-32. Google Scholar.

Mustafa, M. A. (2018). Manajemen Sarana Pendidikan Pada Sekolah Anak Berkebutuhan Khusus Di Sdlb Ytc Kutablang Kabupaten Bireuen. Jurnal Administrasi Pendidikan: Program Pascasarjana Unsyiah,6(1).. Google Scholar.

Nasrudin, N., \& Maryadi, M. (2019). Manajemen Sarana dan Prasarana Pendidikan dalam Pembelajaran di SD. Manajemen Pendidikan, 13(2), $15-$ 23.. https:// doi.org/10.23917/jmp.v13i2.6363.

Novita, M. (2017). Sarana Dan Prasarana Yang Baik Menjadi Bagian Ujung Tombak Keberhasilan Lembaga Pendidikan Islam. NUR EL-ISLAM : Jurnal Pendidikan Dan Sosial Keagamaan, 4(2), 98-129 Google Scholar.

Pramartha, I. N. B. (2015). Sejarah Dan Sistem Pendidikan Sekolah Luar Biasa Bagian a Negeri Denpasar Bali. HISTORIA: Jurnal Program Studi Pendidikan Sejarah, 3(2), 67-74.. Google Scholar.

Purwoko, R. Y. (2017). Urgensi Pedagogicalcontent Knowledge Dalam Meningkatkan Kualitas Pembelajaran Matematika. Jurnal Pendidikan Surya Edukasi (JPSE), 3(2), 42-55.. https:/ / doi.org/10.37729/jpse.v3i2.4338.

Purwari. (2019, 12 February). The Result Interview, Teacher Special Education Waraqil Jannah, at Tanah Datar sub-district, West Sumatera

Sukardi, M. (2014). Penerapan Bimbingan Guru dalam Proses Belajar Mengajar di SDLB. Sekolah Dasar: Kajian Teori dan Praktik Pendidikan, 22(1).. Google Scholar.

Syafe'i, I. (2017). Pondok pesantren: Lembaga pendidikan pembentukan karakter. Al-Tadzkiyyah: Jurnal Pendidikan Islam,8(1), 61-82. https:/ / doi.org/10.24042/atjpi.v8i1.2097.

Triyanto, T., \& Permatasari, D. R. (2017). Pemenuhan Hak Anak Berkebutuhan Khusus Di Sekolah Inklusi. Sekolah Dasar: Kajian Teori dan Praktik Pendidikan, 25(2), 176-186.. http:/ / dx.doi.org/10.17977/um009v25i22016p176.

Wijayanto, H. (2017). Kecukupan FAsilitas Pembelajaran di Sekolah Dasar Luar Biasa Negeri Temanggung. Jurnal Hanata Widya, 6(7), 1-9. Google Scholar

Yusni. (2019, 3 February). The Result Interview, Headmaster of Special Education Waraqil Jannah, at Tanah Datar sub-district, West Sumatera.

Yunandar, N., Koestoro, B., \& Herpratiwi, H. (2017). Pengembangan Modul Kompetensi Pedagogik Guru Pedamping Non PLB Anak Tunagrahita. Jurnal Teknologi Informasi Komunikasi Pendidikan, 5(2).. Google Scholar.

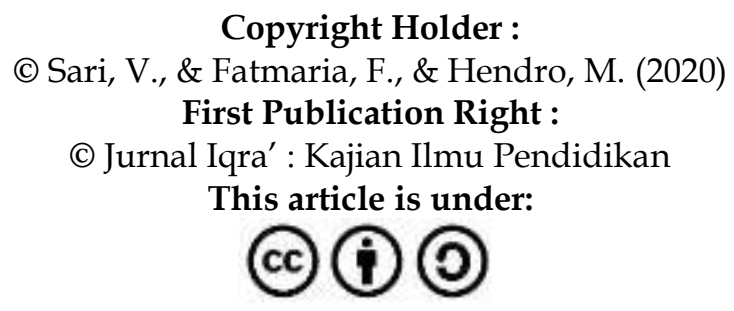

